International Journal of Biology, Pharmaey and Allied Seiences (IJBPAS)

'A Bridge Betueen Caboratory and QRendo'

Www.ijbpas.com

\title{
PHYTOCHEMICAL ANALYSIS AND ASSORTMENT OF ANTIMICROBIAL ACTIVITY OF AEGLE MARMELOS LEAVES: A REVIEW
}

\section{MAJMUNDAR ${ }^{1}$ JA, UPADHAYAY $^{2}$, MARCHAWALA $F^{2}$, BHATTACHARYA ${ }^{2}$ AND ANDHARE $\mathbf{P}^{2 *}$}

1: Student, M. Sc. Microbiology, Parul Institute of Applied Sciences, Parul University, Post Limda, Waghodia, Gujarat, 391760

2: Assistant Professor, Parul Institute of Applied Sciences, Parul University, Post Limda, Waghodia, Gujarat, 391760

*Corresponding Author: E Mail: Dr. Prasad Andhare: prasad.andhare82145@paruluniversity.ac.in; Tel: $+918200614350$

Received 19 ${ }^{\text {th }}$ Jan. 2021; Revised $20^{\text {th }}$ Feb. 2021; Accepted $19^{\text {th }}$ March 2021; Available online $1^{\text {st }}$ April 2021

\section{https://doi.org/10.31032/IJBPAS/2021/10.4.1009}

\section{ABSTRACT}

Phytochemical evaluation and collection of Antimicrobial activity of Aegle marmelos leaves turned into studied. The plant material which includes fruit, leaves of sicknesses unfastened Aegle marmelos from nearby location. the phytochemical evaluation of extracts turned into performed, and antimicrobial activity of ethanol extracts towards diverse traces turned into done. The dried powdered plant material turned into used as solvent extraction the use of solvent Cold water, warm water, ethanol \& n-hexane. The alkaloids have been launched through each ethanol and n-hexane. The Flavonoids, glycosides and saponins have been simplest present withinside the ethanol extract. The tannins have been present withinside the n-hexane extract. Antimicrobial activity of the extracts turned into decided towards a few human pathogenic microorganism and fungi which include Staphylococcus aureus, Escherichia coli, Streptococcuspneumoniae, Bacillus subtilis and Candida albicans the use of the agar nicely diffusion and broth dilution strategies with the polar extract being greater 
powerful. Thus, in future, extract of Aegle marmelos can be useful for some other numerous species of microbes.

Keywords: Aegle marmelos, Phytochemical analysis, Antimicrobial activity

\section{INTRODUCTION}

Plants were used as an herbal useful resource of medicinal compounds considering that many years. Human is the use of many flora and plant acquired out come to heal and assist from diverse bodily and intellectual sicknesses [1]. The cap potential to manufacturing combos through minor hobby ingesting disinfectant viable types flora a treasured supply of recovery and recovery goods. The talent of plant extracts on microbe has been taken into consideration worldwide. Bael (Aegle marmelos) has been recognized to be simplest of the farthest critical remedial flora of India from the time while Charak (1500 B.C) [2]. Aegle marmelos is a medicinal plant that is a satisfactorily great, quick and clean tree with extra again born and typically trifoliate leaves affiliation to the own circle of families, Rutaceae. Aegle marmelos is regularly namedvilvam in Tamil, bael in Hindi, sripal or bilwa in Sanskrit and bael tree in English [3]. The natural relay of the mixtures immediately in those medicinal flora displays their pastime in take care of sicknesses like dysentery, diarrhea, belly pain, dyspepsia. In the beyond few years a few plant species were examine and evaluated for his or her antimicrobial pastime [4]. Aegle marmelos is an herbal plant of India. Aegle marmelos have its location to Rutaceae own circle of relatives and typically identified as wooden apple. In India, Aegle marmelos is adult as a sanctuary rockery plant and the leaves are used to implore Aristocrat Shiva. Aegle marmelos is an enormous remedial plant with a few ethnomedicinal claims in conventional and famous remedial structures. Habitually, Aegle marmelos is cast-off withinside the dealing of diarrhea and dysentery. Leaves of this plant cast-off to purpose sterility/miscarriage in women. Just, the plant is separated for its remedial assets through systematic structures and knowledgeable for lots remedial assets [5]. The medicinal houses of Aegle marmelos plant were associated withinside the Ayurveda which relocate as recognition of being 5000 years again to the historic Sanskrit text, the Vedas. It is as new and advantageous to human beings at cuttingedge because it turned into withinside the historic instances but more material and relevant in those cutting-edge instances [6].

\section{Plant morphology:}

The tree cultivates in prepare well-shattered dirt up to regarding twelve to fifteen $\mathrm{m}$. in altitude, level within the exacting and parched climates. They need prickly 
divisions and substitute leaves with tierce to 5 ovals, pointed, frivolously saw-like brochures. The floras area unit aromatic and area unit produce in collections sideways the new brushwood [7]. The eatable berries also are rounded, oval or parallelogram in form. Conditional on their selection, the paste of fruits is also encircled by a tinny or powerful woody bomb that's gray-green in shade once raw and yellow once ripe [8]. Flowering happens in Gregorian calendar month and will later the new leave. Aromatic flowers, in bunches of four to seven sideways the new subdivision lets, have four curved, plump petals, inexperienced external, yellow exclusive, and fifty or additional yellowness stamens [9].

\section{Distribution of Aegle marmelos:}

Aegle marmelos is a subtropic plant and cultivates as much as an elevation of 1,2 hundred $\mathrm{m}$ elevation from marine equal. It cultivates first-rate withinside the dehydrated jungles on mountainous and easy zones. Aegle marmelos is a widely unfold plant and create in India, Ceylon, China, Nepal, Sri Lanka, Myanmar, Pakistan, Bangladesh, Nepal, Vietnam, Laos, Cambodia, Thailand, Indonesia, Malaysia, Tibet, Sri Lanka, Java, Philippines and Fiji. In India it located in Sub-Himalayan tracts from Jhelum eastwards to West Bengal, in imperative and south India. It originates sincerely in all of the states of India. Aegle marmelos is diagnosed with the aid of using numerous names in numerous components of world [10].

\section{Folklore claims of Aegle marmelos:}

Table 1: In India, tribes of various states use the parts of this plant to treat several ailments.

\begin{tabular}{|c|c|c|}
\hline TRIBAL & $\underline{\text { USES }}$ & $\underline{\text { Reference }}$ \\
\hline Santhal & $\begin{array}{l}\text { They custom the plant as remedy for bell pain, cholera, night } \\
\text { time fever, belly contamination and snake bite. They custom } \\
\text { in particular end result and roots for beneficing gastric } \\
\text { problems }\end{array}$ & [11]. \\
\hline $\begin{array}{c}\text { Bhottada tribe of } \\
\text { Orissa }\end{array}$ & $\begin{array}{l}\text { They utilization the origins of Bael for recovery part of mad } \\
\text { canine }\end{array}$ & [11]. \\
\hline $\begin{array}{l}\text { Tribal of Ranchi } \\
\text { district of Bihar }\end{array}$ & $\begin{array}{c}\text { They use the verdures of Bael for remedy of warmth in } \\
\text { stomach and jaundice. }\end{array}$ & [11]. \\
\hline Gujarat & \begin{tabular}{|l} 
They use the leaves for treating abscess \\
\end{tabular} & [11]. \\
\hline $\begin{array}{l}\text { Tribal of } \\
\text { Southern } \\
\text { Rajasthan }\end{array}$ & $\begin{array}{l}\text { They use root bark as fish Poison and utilize the leaf paste as } \\
\text { an antivenom towards venom of toxic bugs and animals. The } \\
\text { capacity of fruit and bark is utilized for the remedy of } \\
\text { bellyache and dysentery in jap Rajasthan. }\end{array}$ & [12]. \\
\hline Uttar Pradesh & $\begin{array}{l}\text { they utilized the fruit as asevere and tonic. Tribal of Eastern } \\
\text { U.P. make use of the leaves for the remedy of cuts and } \\
\text { wounds of humans in addition to animals. The leaves are } \\
\text { used as antidiabetic agent in Terai place of U.P }\end{array}$ & [11]. \\
\hline Assam & They use the leaves for back pain and sickness & [13]. \\
\hline Andhra Pradesh & $\begin{array}{l}\text { The bark is used for therapeutic of looseness and root for } \\
\text { bone fracture. }\end{array}$ & [11]. \\
\hline Maharashtra & They utilized the leaves to cure diabetes & [11]. \\
\hline Madhya Pradesh & $\begin{array}{l}\text { The roots are used for treating palpitation of heart. People } \\
\text { agree with that an attraction to the Bilva tree and to } \\
\text { Dhanvantari, the doctor of Gods, therapies snake bite. }\end{array}$ & [14]. \\
\hline $\begin{array}{l}\text { Jammu and } \\
\text { Kashmir }\end{array}$ & The fruit is utilized as a laxative & [11]. \\
\hline
\end{tabular}




\section{Nutritional value of Aegle marmelos:}

The fruit of Aegle marmelos keep high nutritious value. The akene is employed to create juice, jam, sirup, jelly, toffy and more foodstuffs. The paste is selected to hide water, sugars, protein, fiber, fat, calcium, phosphorus, potassium, Iron, minerals and vitamins (Vitamin A, Vitamin B1, vitamin C and Riboflavin). The leaves and also the bud of the plant area unit used as inexperienced vegetable in state [15].

\section{Ethnobotanical use:}

The pulp of the fruit is pleasantly seasoned and sugar-coated to style. it's accustomed build a widespread summer soak up Indian subcontinent: the straightforward pulp is scooped, cored and unified with milk, sugar and cardamom, and is gone as a state change drink. The semi-ripe fruits area unit employed in creating jam by adding sugar, acid and preservatives. Dry pulp is additionally eaten up. Apart once its dietary value, Aegle marmelos is historically careful as an excellent Ayurvedic medication for looseness of the bowels. The immature fruits, that area unit bitter, acrid, sour, and harsh, aid in interest and abdomen irritation. The half-ripe fruits area unit severe, abdominal and medicinal drug. The ready fruits area unit unreal to be further helpful than the rare fruits and area unit accustomed avoid acute and lasting infectious disease. Their leaves area unit sometimes utilized for the handling of temperature, abdominal pain, urinary difficulties, heart palpitation, dysentery, upset stomach, abdominal ache, formative faintness, nausea and swellings [16].

Phytochemical composition of Aegle marmelos:

Different organic extracts of the leaves of Aegle marmelos are knowing to own alkaloids, viscus glycosides, terpenoids, saponins, tannins, flavonoids and steroids. Aegle marmelos fruit pulp knowing for the obtainability of steroids, terpenoids, flavonoids, phenolic resin compounds, lignin, fat and oil, inulin, proteins, carbohydrates, alkaloids, viscus glycosides and flavonoids [17].

\section{Phytochemical analysis:}

Phytochemical try involved from the gathering of plant cloth to the take a glance at middle consider whereby the plant cloth conjointly from varied reasserts and perform varied chemical consider to return to be the required outcome. The resolve of our phytochemical studies become to isolate the dynamic chemical parts gift day withinside the leaves of Aegle marmelos [18]. around, Aegle marmelos leaves restricted $\gamma$-sitosterol, aegelin, lupeol, rutin, marmesinin, $\beta$ - sitosterol, flavone, glycoside, Oisopentenylhalfordiol, marmeline and phenylethyl cinnamamides.

1. Alkaloids: The alkaloids incorporate the foremost necessary unmated magnificence of secondary plant substances. Four 
alkaloids are aforementioned from dry leaves of Aegle marmelos N-2-[4-(3',3'dimethylallyloxy) phenyl] ethylcinnamide, N-2-hydroxy-2[4- $\left(3^{\prime}, 3^{\prime}-\right.$ dimethylallyloxy) phenyl] ethylcinnamide or marmeline, N-4- methoxy styryl cyanamide and N-2-hydroxy-2-(4hydroxyphenyl) ethylcinnamide and aegeline. Aegeline become to start with believed to stand a steroid but when a vital consider it become determined to be associate impartial gas compound. Recently, assortment of phenylethyl cyanamides, that protected new mixtures named anhydromarmeline, aegelinosides A and B are remoted from Aegle marmelos leaves as $\alpha$-glucosidase inhibitors. The present ending in addition helps ethno medicine use of Aegle marmelos as a treatment for diabetes mellitus. Associate uncommon organic compound, shahidine, having a risky oxazoline center has been remoted as a primary integral from the sparkling leaves of Aegle marmelos. it's moisture-sensitive, and confirmed to be the determine multiple of aegeline and totally different amides; but, it's miles sturdy in dimethyl sulfoxide. Its form become put in with the help of victimization spectroscopy. Biogenetically, oxazolines may be taken into thought as a result of the pioneer of chemical group amides and oxazole determined in plants. Shahidine confirmed hobby towards some Gram-fantastic bacterium [19].

2. Phenylpropanoids: These area unit clearly happening phenoplast compounds, that have a scented ring to that three-carbon side chain is connected. Among the phenylpropanoids area unit blanketed hydroxycoumarins, phenylpropenes and lignans. the largest plant coumarin is that the figure compound, coumarin itself, that takes place in over twenty-seven plant families. Marmesin become originated as a spic-and-span compound from leaves, that is likewise a constituent of wood and root26. Aegelenine, a minor base of the leaves, that become to start out with claimed to be a spic-and-span compound, become exposed to be same to halfordinol, the straightforward constituent of Halfordiascleroxyla. Aegeline (N-[2hydroxy-2(4-methoxyphenyl) ethyl]-3phenyl-2-propenamide) could be a recognized constituent of the bael leaf and wolfed as a nutritionary complement for quite a few purposes [29, 30, 24]. contemporary leaves on distillation yield yellowish-inexperienced oil with associate uncommon scented odourmarmelosin, marmesinine, $\beta$ - sitosterol- $\beta$-D-glucoside and rutin withinside the leaves. Marmenol, a fresh 7-geranyloxycoumarin [7-(2,6dihydroxy-7- methoxy-7-methyl-3octaenyloxy) coumarin] become remoted 
from the leaves of methanolic extract of Aegle marmelos. [20].

3. Terpenoids:The important oil of Aegle marmelos Correa leaves turned into studied very a lot substantially in India through diverse people seeing that 1950. $\alpha$ Phellandrene turned into observed to be the not unusual place fundamental of the important oil from leaves, twigs and fruits32,33. $\alpha$-Phellandrene $(56 \%)$ and $p$ cymene $(17 \%)$ have been pronounced from leaf oil. Later, comparable file turned into posted on leaf important oil through many people. p-Menth-1-en-3,5-diol turned into remoted and characterized from Aegle marmelos leaves. Limonene (82.4\%) turned into pronounced as the principal constituent from Aegle marmelos leaves and it turned into proven that limonene is feature marker for identity of Aegle marmelos oil samples36. $\gamma$-Sitosterol turned into diagnosed from the leaves [21].

4. Tannins: There is as a lot as $9 \%$ tannin withinside the pulp of untamed fruits, much less in cultivated type. Tannin is likewise found in leaves as skimmianine. It is likewise named as 4, 7, 8-trimethoxyfuroquinoline [22].

5. Flavonoids: Mainly consists of Rutin, flavone, flavan-3-ols, flavone glycosides. In a take a look at essential medicinal flowers have been investigated at the phytochemical composition which includes Aegle marmelos and pronounced maximum alkaloids (1.08\%), tannins $\quad(15.26 \%)$, Flavonoid $(0.98 \%)$ and saponins $(2.62 \%)$ in Aegle marmelos leaves whilst as associated with different plants. A take a look at carried out qualitative and quantitative phytochemical evaluation, antimicrobial pastime and decided bio-energetic additives turned into carried out from 18 varieties/accessions of the leaves of Aegle marmelos from throughout India and it turned into discovered that the crude extracts of Aegle marmelos discovered the occurrence of numerous biologically energetic phytochemicals with the best number of alkaloids, flavonoids, and phenols in Pant Aparna variety. The GCMS evaluation discovered the presence of many bioactive compounds along with flavonoids, alcohols, aldehydes, fragrant compounds, fatty acid methyl esters, terpenoids, phenolics, and steroids that may be postulated for antibacterial pastime [23]. 6.Seed oil:Seed oil is bitter and consists of $15.6 \%$ saturated fatty acid, $8.3 \%$ octadecanoic acid, 28.7\% linolic acid and seven. $6 \%$ omega-6 whilst seed residue consists of roughly seventieth proteins [24]. 7. Miscellaneous compounds: Praealtin D, trans-cinnamic acid, valencic acid, 4methoxybenzoic acid, betulinic acid, N-pcis- \& transcoumaroyltyramine, montanine, and rutaretin from the leaves of methanolic extract of Aegle marmelos. Rutin, flavan-3ols, anthocyanins, lecucanthrocyanins, 
flavone glycosides and tannins to boot had been pronounced from the leaves24 [25].

\section{Antimicrobial Activity:}

Aegle marmelos has been generally utilized for the dealing with of the many infectious ailments and been extendible outlined to save lots of you the in-depth form of infective microbes. many in vitro researches tested the antimicrobic viable of Aegle marmelos extracts to the infective microbes and organism and fungi [26]. The antimicrobic interest of the leaves of Aegle marmelos became finished with the help of using agar properly diffusion technique. The binary compound, crude oil ether and alcohol extract of the leaves of Aegle marmelos displayed inexperienced antimicrobial motion towards Escherichia coli, eubacteria pneumoniae, salmonella, enterics pneumoniae and Proteus vulgaris. The ethanolic extract indicates interest towards genus Penicillium chrysogenum and also the crude oil ether and binary compound extract shows motion towards Fusarium oxysporum [27]. The antimicrobial interest of the leaves of Aegle marmelos became privy. The antimicrobial interest became take a look at with the help of victimization disc diffusion methodology. The crude oil ether extract of leaves became checked as compared to multi resistant traces Staphylococcus aureus, Bacillus subtilis, Escherichia coli, Salmonella typhi, Proteus vulgaris,
Pseudomonas aeruginosa and Klebsiella pneumonia [28]. Worked on antimicrobial interest of ethanolic leaf extracts of Aegle marmelos on selected microbic traces. Phytochemicals current withinside the ethanolic leaf extracts of Aegle marmelos show substantial medication interest. More, at awareness of $300 \mu \mathrm{l}$ and on top of, ethanolic leaf extracts of Aegle marmelos tested huge interest within the direction of all the chosen microorganism traces. However, B. subtilis and E. coli had been bigger touchy within the direction of the remedy whereas compared to $S$. aureus, $P$. aeruginosa and K. pneumonia [29]. The bactericide value became nonheritable in binary compound extract con to $S$. epidermidis, despite the very fact that methanolic extract became originate durable con to $S$. aureus. However, in aqueous: alcohol, the most effective consequences are placed con to $E$. aerogenes. Bioactive combos like flavonoids, alcohols, aldehydes, musky compounds, carboxylic acid alkyl group esters, terpenoids, phenolics, and steroids which will be taken into thought as in command of bactericide activity [30]. a few years past, the remedial flora is freelance used as a movement while not tremendous the energetic compound in value for remedial the infection and indexed fifty healing flora having bactericide things tested through precent day analysis [31]. 


\section{CONCLUSION}

It is relativelyobvious from this analysis that Aegle marmelos a very major medicative herb and broadly employed in Ayurveda, Siddha and alternative medicative systems. Aegle marmelos comprisesvariation of phytoconstituents, that area unit the key features within the medicative worth of this plant. Aegle marmelos contains variety of phytoconstituents, that area unit the key features within the medicative worth of this plant. the mainstream components of this position like leaf, fruit, seed, bark and root area unit want to treatment a range of diseases. These studies have highlighted the medicative activity and presence of probably active drug parts in Aegle marmelos, that may be advanced as originaldrug for dealing, bar or relief of polygenic disease, cancer and numerous morbific poisons. any analysis could also be desirable to evaluate the biotic activity of the energetic parts. A basic innovative work has to be bound to be comprised for the progression of drugs for his or her advancedeconomic and remedial usage.

\section{ACKNOWLEDGEMENT}

It is our privilege and honour to express our sincerest gratitude to the Parul University, Vadodara, Gujarat for providing me all the necessary support and facilities including state of the art infrastructural facilities with advanced technological scientific laboratories and everything else that was required to carry out this work.

\section{REFERENCE}

[1] Sekar, D. K., Kumar, G., Karthik, L., \& Rao, K. B. (2011). A review on pharmacological and phytochemical properties of Aegle marmelos (L.) Corr. Serr. (Rutaceae). Asian Journal of Plant Science and Research, 1(2), 8-17.

[2] Mujeeb, F., Bajpai, P., \& Pathak, N. (2014). Phytochemical evaluation, antimicrobial activity, and determination of bioactive components from leaves of Aegle marmelos. BioMed research international, 2014.

[3] Selvaraj, R., Rani, S. J., Kumar, N. M., \& Natarajan, A. (2015). Antimicrobial screening and phytochemical analysis of Aegle marmelos against enteric pathogens. International Journal of PharmTech Research, 8(2), 244-249.

[4] Behera, P., Raj, V. J., \& Basavaraju, R. (2014) Phytochemical and antimicrobial activity of fruit pulp of Aegle marmelos. Journal of chemical and pharmaceutical Research, 6(8), 319-326.

[5] Nigam, V., \& Nambiar, V. S. (2015). Therapeutic potential of Aegle marmelos (L.) Correa leaves as an antioxidant 
[6] Gupta, A., Thomas, T., \& Khan, S. (2018).

Physicochemical,

Phytochemical Screening and Antimicrobial Activity of Aegle marmelos. UKJPB, 6(3), 17-24.

[7] Neeraj, V. B., \& Johar, V. (2017). Bael (Aegle marmelos) extraordinary species of India: a review. Int J Curr Microbiol App Sci, 6(3), 1870-1887.

[8] Blancke, R. (2016). Tropical fruits and other edible plants of the world: An illustrated guide. Cornell University Press. and anti-diabetic agent: a review. International Journal of Pharma Sciences and Research, 6(3), 611-621.

[9] Mali, S. S., Dhumal, R. L., Havaldar, V. D., Shinde, S. S., Jadhav, N. Y., \& Gaikwad, B. S. (2020). A Systematic Review on Aegle marmelos (Bael). Research Journal of Pharmacognosy and Phytochemistry, 12(1), 31-36.

[10] DeFilipps, R. A., \& Krupnick, G. A. (2018). The medicinal plants of Myanmar. PhytoKeys, (102), 1

[11] Gupta, R. (2016). Ethnobotanical studies of Bael (Aegle marmelos): A sacred plant of Hindus. International Journal of Herbal Medicine, 4(4), 114-115.

[12] Joshi, P. (1986). Fish Stupefying Plants Employed By Tribals Of
Southern

Rajasthan-A

Probe. Current Science, 647-650.

[13] Bhattacharjee, S., Tiwari, K. C., Majumdar, R., \&Misra, A. K. (1980). Folklore medicine from district Kamrup (Assam). Bull Medic-Ethno-Bot Res 1980, 1.

[14] Wagh, V. V., \& AK, J. (2014). Ethnomedicinal uses of underground plants parts in Jhabua district, Madhya Pradesh, India. Adv Biol Res, 8(4), 151-156.

[15] Bhatt, D. K., \& Verma, S. A. (2016). Study on Development of Herbal Food Product Bael (Aegle Marmelos) Fruit Toffee. Journal of Environmental Science, Toxicology and Food Technology., 5-14.

[16] Nathan, J. (2017). King Solomon's Table: A Culinary Exploration of Jewish Cooking from Around the World. Knopf

[17] Sivakumar, G., Gopalasatheeskumar, K., Gowtham, K., Sindhu, E., Akash Raj, K., Rajaguru, B., \& Kalaichelvan, V. K. (2020). Phytochemical analysis, Antioxidant and Antiarthritic activities of different solvent extract of Aegle marmelos L. unripe fruit. Phytochemical analysis, 15(2.262), 15-08. 
[18] Afroge, S. E. A. (2009). Literature Review and Phytochemical Analysis on Stem Bark of Aegel marmelos (Doctoral dissertation, East West University).

[19] Nigam, V., \& Nambiar, V. S. (2015). Therapeutic potential of Aegle marmelos (L.) Correa leaves as an antioxidant and anti-diabetic agent: a review. International Journal of Pharma Sciences and Research, 6(3), 611-621.

[20] Pawar, R. S., \& Grundel, E. (2017). Overview of regulation of dietary supplements in the USA and issues of adulteration with phenethylamines (PEAs). Drug testing and analysis, 9(3), 500517.

[21] Yadav, N. P., \& Chanotia, C. S. (2009). Phytochemical and pharmacological profile of leaves of Aegle marmelos Linn. The Pharmaceutical Reviews, 144-159.

[22] Gupta, E., Shakyawar, S., \& Sundaram, S. (2019). Therapeutic and Nutraceutical Potential of Bioactive Compounds in Aegle marmelos (L.): An Overview. Current Nutrition \& Food Science, 15(4), 306-317.

[23] Campos-Vega, R., Nieto-Figueroa, K. H., \& Oomah, B. D. (2018). Cocoa (Theobroma cacao L.) pod husk: Renewable source of bioactive compounds. Trends in Food Science \& Technology, 81, 172-184.

[24] Humane, M. M., Bornare, D. T., Babar, K. P., Ghorad, A. S., \& Kahar, S. P. (2018, June). Microencapsulation of Bael Seed Oil. In International Journal of Innovative Research and Creative Technology (Vol. 3, No. 6 (June2018)). IJIRCT.

[25] Ali, M. S., \& Pervez, M. K. (2004). Marmenol: A 7geranyloxycoumarin from the leaves of Aegle marmelos L. corr. Natural Product Research, 18(2), 141-146.

[26] Gupta, A., Thomas, T., \& Khan, S. Phytopharmacological Potentials and Micropropagation of Aegle marmelos-A Review.

[27] Vashist, H., \& Jindal, A. (2012). Antimicrobial activities of medicinal plants-Review. International Journal of Research in Pharmaceutical and Biomedical Sciences, 3(1), 222-230.

[28] Pawaskar, S. M., \& Sasangan, K. C. (2017). Preliminary phytochemical and in vitro-antimicrobial analysis of Annona squamosa linn. leaf extract. Journal of Pharma- 
ceutical Sciences and Research, $9(5), 618$.

[29] Ramya, S., Jayakumararaj, R., Krishnasamy, G., Periathambi, N., \& Devaraj, A. (2012). Antibacterial activity of ethanolic leaf extracts of Aegle marmelos (L) CORR. International Research Journal of Pharmaceutical and Applied Sciences, 2(6), 74-79.

[30] Bairy, K., \& Abhinav, R. (2011). AIN-1 Evaluation of burn wound healing activity of topical regular insulin in normal and diabetic rats. Indian Journal of Pharmacology, 43(7), 41-197.

[31] Sivananthan, M. (2013). Antibacterial activity of 50 medicinal plants used in folk medicine. Int. J. Biosci, 3(4), 104121. 